\title{
SUBSIDIARY PROTECTION AND PRIMARY RIGHTS
}

\author{
RYSZARD PIOTROWICZ* AND DR CARINA VAN ECK**
}

\section{INTRODUCTION}

On 12 September 2001 the Commission of the European Communities published its Proposal for a Council Directive laying down minimum standards for the qualification and status of third country nationals and stateless persons as refugees, in accordance with the 1951 Convention relating to the status of refugees and the 1967 protocol, or as persons who otherwise need international protection ${ }^{1}$ (Proposal).

As the Explanatory Memorandum contained in the Proposal indicated, it was supposed to create 'the heart of the Common European Asylum System', as envisaged in the Conclusions of the Presidency at the Tampere European Council in October 1999. ${ }^{2}$ This system is intended to be based on the 'full and inclusive application of the Geneva Convention' ${ }^{3}$ that is, the Member States recognise the central place of the Convention ${ }^{4}$ in their treatment of asylum seekers, which means that those entitled to Convention refugee status will get it. Furthermore that recognition of the importance of the Convention, as well as the duty to apply it fully and inclusively, acknowledges the significance of refugee status in the Proposal, in particular, during a period of major development in the European regime, the need to avoid downgrading traditional refugee status. ${ }^{5}$

* Professor of Law, University of Wales, Aberystwyth.

** UNHCR, Geneva. The views expressed in this article are personal to the authors and do not necessarily reflect the views of the UNHCR.

1 COM(2001) 510, 2001/0207 (CNS), ASILE 52, 13620/01

2 Presidency Conclusions, Tampere European Council, SI (1999) 800, Conclusions 13 and 14.

3 Ibid, Conclusion 13.

4 Convention relating to the status of refugees 1951 (189 UNTS 150) as amended by the 1967 Protocol (606 UNTS 267).

5 This caution is of utmost importance, as there has been a tendency in State practice over the last decades to interpret the refugee definition in Art 1 of the Convention in a more restrictive manner in answer to the increase in the number of asylum seekers. Varying interpretations by Member States result in widely differing recognition rates of persons in the same circumstances; refugees who may be granted refugee status in one Member State may be denied such status in another. Often these persons will be granted some sort of subsidiary status or a (temporary) residence permit for compassionate reasons. See for examples of this in Dutch and German law and policy: C van Eck, De-facto-Fluechtlinge, Europäische Hochschulschrifte, Reihe II, Vol 2777 (1999). This development was already acknowledged by the Council of Ministers of the Council of Europe in Resolution (84)1 of 25 Jan 1985. See also Recommendation of the Parliamentary Assembly of the Council of Europe (67) 787, para 3, in which the Assembly expresses its worries concerning 'the widely differing recognition rates in the various states, which are the result of the adoption of different criteria and, in part, of reliance upon inadequate information ...' and para 4

[ICLQ vol 53, January 2004 pp 107-138] 
The reality with which we are confronted is that many asylum seekers fleeing the most serious threats to their basic human rights are not necessarily protected by the Convention regime. In recognition of this there has developed the principle of subsidiary protection as a kind of safety net for those who fail to qualify as Convention refugees, but who are nevertheless recognized to be in need of international protection. ${ }^{6}$

The widely varying interpretations of the 1951 Geneva Convention and in particular of the State practice of the granting of alternative forms of prolonged stay, such as subsidiary protection, revealed the need for harmonisation within the EU in order to ensure that a minimum level of protection is available in all Member States and that disparities in Member States' legislation and policy would be reduced. ${ }^{7}$ This was formalized in the Proposal, so that effectively there will be two categories of persons in need of international protection: ${ }^{8}$ Convention refugees and those entitled to subsidiary protection. ${ }^{9}$

'refugee status granted in one state is not necessarily recognised in other state parties to the same conventions'.

${ }^{6}$ Acknowledgment of this notion may be found, for example, in Recommendation (76) 773 of the Parliamentary Assembly of the Council of Europe, which refers to 'persons not recognised as refugees within the meaning of Art 1 of the Convention relating to the status of refugees ... and who are unable or unwilling for political, racial, religious or other valid reasons to return to their countries of origin'. See also: UNHCR EC/50/SC/CRP.18 of 9 June 2000. See also D Bouteillet-Paquet (ed), Subsidiary Protection of Refugees in the European Union: Complementing the Geneva Convention? (Bruxelles Bruylant 2002).

7 This need appears already from the Council Resolution of Oct 1996 on the establishment of priorities for cooperation on judicial and internal affairs for the period from 1 July 1996 to 30 June 1998 (OJ C 319, 26 Oct 1996, 1) and was confirmed in the Council Resolution setting priorities from 1 Jan 1998 until the date of entry into force of the Amsterdam Treaty (OJ C 11, 15 Jan 1998, 1). Accordingly the Dutch presidency prepared a note on subsidiary protection (ASIM 89, $7779 / 97$ of 28 Apr 1997) which was followed up by the Danish presidency, which presented a note for discussion on various forms of subsidiary protection and the need for harmonisation within the EU (ASIM 52, 6764/97 of 17 Mar 1997). It was considered that, after the adoption of the EU Joint Position of 4 Mar 1996 concerning the harmonized application of the definition of the term 'refugee' in Art 1A of the Geneva Convention, and pursuant to the provisions of the Dublin Convention, a harmonised concept of subsidiary forms of protection was needed, as 'the overall assessment of the application ... will rarely be finally concluded by a decision ... pursuant to the Geneva Convention. Thus - before return ... it will often be necessary to consider the applicant's need for protection on another basis. Where differences exist between the national schemes in Member States concerning alternative forms of protection, it may become of vital importance to the applicant, in connection with return under the rules of the Dublin Convention, to which Member State he or she is returned' (4).

${ }^{8}$ The use of the term 'international protection' in this context has been criticized by the UNHCR. Its point is that international protection is the prerogative of the UNHCR, and that States more accurately give national protection in performance of an international obligation. Accordingly the UNHCR suggests that 'asylum' would be a more appropriate term: UNHCR, Observations on the European Commission's proposal for a Council Directive on minimum standards for the qualification and status of third country nationals and stateless persons as refugees or as persons who otherwise need international protection (Observations), Nov 2001, paras 9-10. Although UNHCR is strictly speaking right about the meaning of this term, we are of the opinion that in the context of the Proposal the use of the term 'international protection' is useful as an overarching notion, containing two categories in need of protection, and does not lead to any confusion in this context.

9 Tampere Conclusion 14 provides, in part: '[The Common European Asylum System] should 
The Proposal is just one of a plethora of measures addressing asylum issues in the context of the European harmonization process. As such it forms part of the effort to create a Common European Asylum System in the longer term, implementing Article 63 (1)(c) and 2(a) of the EC Treaty. ${ }^{10}$ The initiative, along with the other measures being prepared as part of that system, highlights a major trend in refugee law: that it is not simply Geneva driven. It aimed approximate the diverse State practice in the area. ${ }^{11}$ What we see now is a European system of asylum law the provenance of which is located as much in Brussels as in Geneva.

However, the Proposal has been substantially amended by the Council in the course of continuous negotations. ${ }^{12}$ This article analyses the notion of subsidiary protection in the Proposal and in the amended Proposal, and considers the extent to which they develop, codify or, indeed, fail to reach the level of protection required by the law on protection of non-Convention refugees. In this respect one of the most significant issues concerns the extent to which international law already binds States to provide protection to the groups identified in Article 15 of the Proposal. This is particularly significant because the amended Proposal in fact reduces the scope of beneficiaries of subsidiary protection in comparison to the original Proposal.

Subsidiary protection as a concept recognizes that not all persons in need of international protection are included in the definition of refugees contained in the Convention. As such they are not entitled to protection under that instrument. Nevertheless, it is now well recognized, ${ }^{13}$ among

also be completed with measures on subsidiary forms of protection offering an appropriate status to any person in need of such protection.'

10 'The Council . . . shall, within a period of five years after the entry into force of the Treaty of Amsterdam, adopt: (1) ... (c) minimum standards with respect to the qualification of nationals of third countries as refugees; ... (2) measures on refugees and displaced persons within the following areas: (a) minimum standards for giving temporary protection to displaced persons from third countries who cannot return to their country of origin and for persons who otherwise need international protection ...' Concerning the setting of minimum standards for the qualification and status of persons eligible for subsidiary protection in particular, it is clear that Art 63(2)(a) is the appropriate legal basis: Legal Service of the EC, ASILE 34, JUR 247, 10560/02 of 10 July 2002.

11 F Roscam-Abbing, 'Subsidiary Protection: Improving or Degrading the Right of Asylum in Europe?', in Bouteillet-Paquet n 6 above 43, at 50-1.

12 See for the result of negotiations until 26 Nov 2002: 14643/1/02 Rev 1; ASILE 68 (amended Proposal); subsequently 10576/03, ASILE 40, 19 June 2003.

13 The UNHCR has expressly raised this in a commentary on migration control in the European Union: Office of the UN High Commissioner for Refugees, Reconciling Migration Control and Refugee Protection in the European Union: A UNHCR Perspective (Oct 2000) para 40: 'the Convention definition of a refugee does not cover the protection needs of all persons. Those who may not necessarily come within the ambit of the Convention refugee definition as formulated in 1951 but who nevertheless need international protection are commonly referred to as refugees falling under UNHCR's wider competence. States have long supported protection and assistance activities undertaken for those categories of refugees by UNHCR, which include, for example, persons fleeing the indiscriminate effects of armed conflict or serious public disorder, albeit with no specific element of persecution or link to one of the five grounds enumerated in the Convention', <http://www.unhcr.ch/refworld/refworld/legal/refpol/migrtne.pdf $>$. See also: UNHCR, Complementary forms of protection, EC/50/SC/CRP 18, 3. 
others by State practice, ${ }^{14}$ that such persons may be entitled to international protection because of threats to their human rights. In particular, but not exclusively, State obligations towards such persons may be triggered because of duties arising under Article 3 of the European Convention on Human Rights and Fundamental Freedoms (ECHR), ${ }^{15}$ Article 3 of the UN Convention against Torture and other Cruel, Inhuman or Degrading Treatment (CAT), ${ }^{16}$ and Article 7 of the International Covenant on Civil and Political Rights (ICCPR).${ }^{17}$ The regime of subsidiary protection, including rights and benefits, is intended to establish a harmonised system of protection by EU Member States for those in need of international protection but not covered by the Convention.

\section{SUBSIDIARY PROTECTION IN THE PROPOSALS}

\section{A. The Original Proposal}

The Proposal outlined the notion of subsidiary protection as a reflection of the extended scope of international protection based upon human rights instruments and State practice, complementing the 1951 Geneva Convention: Article 2(e) and Article 5(2).

Article 5(2) made it clear that subsidiary protection is not a blanket protection measure. On the other hand, it stated clearly that granting of subsidiary protection, once the applicants fulfilled the criteria laid down in Article 5(2) in conjunction with Article 15, is not in the discretion of Member States: it is an obligation, not intended to create new obligations for Member States ratione personae, but rather to codify existing international human rights obligations and the best elements of different systems in the Member States. ${ }^{18}$ Furthermore, the Proposal clearly limited subsidiary protection to the need for international protection; prolonged stay or residence based upon

14 Report on the State practice within the EU, ASIM 267, 13667/97 6 Jan 1998. In Member States different terms are used in this context, such as temporary residence, exceptional leave to remain, tolerated status, or a de-facto-refugee status.

15213 UNTS 221. Art 3 of the ECHR provides: 'No one shall be subjected to torture or to inhuman or degrading treatment or punishment.'

16 1984, GA Res 39/46. Art 3 of CAT provides: '1. No State Party shall expel, return ('refouler') or extradite a person to another State where there are substantial grounds for believing that he would be in danger of being subjected to torture. 2. For the purpose of determining whether there are such grounds, the competent authorities shall take into account all relevant considerations including, where applicable, the existence in the State concerned of a consistent pattern of gross, flagrant or mass violations of human rights.'

17 GA Res 2200 (XXI) (1966). Art 7 of the ICCPR provides: 'No one shall be subjected to torture or to cruel, inhuman or degrading treatment or punishment. In particular, no one shall be subjected without his free consent to medical or scientific experimentation.'

18 Explanatory Memorandum, para 3,6. The wide diversity of State practice is illustrated by the report of the Council of the European Union on Alternative Forms of Protection to Refugee Status under the Geneva Convention, 12 Oct 2000, Doc No 12261/00. 
family ties or compassionate reasons not linked to international protection were not covered. ${ }^{19}$ Provisions dealing with family reunification or otherwise respecting family unity, as well as circumstances relating to medical circumstances or age, would either be addressed in other EU instruments ${ }^{20}$ or else be left to remain regulated under national law. Also, purely practical or logistical reasons for non-expulsion, for instance because of a lack of transport connections or the necessary documents, were not covered. Temporary protection - the specific interim response to a mass influx as a result of a calamity in the country of origin, where large numbers of arrivals overwhelm the system for determining protection needs and where timelimited safety and protection must be granted to groups of persons, was also excluded. ${ }^{21}$

Under Article 5(2),

subsidiary protection shall be granted to any third country national or stateless person who does not qualify as a refugee, according to the criteria set out in Chapter III of this Directive, or whose application for international protection was explicitly made on grounds that did not include the Geneva Convention; and who, owing to a well-founded fear of suffering serious and unjustified harm set out in [A]rticle 15, has been forced to flee or to remain outside his or her country of origin and is unable or, owing to such fear, is unwilling to avail himself of the protection of that country.

The requirement, then, was that there be a fear of 'serious and unjustified harm'. This was to some extent clarified by Article 15, which established three types of harm as sufficient to qualify:

(a) torture or inhuman or degrading treatment or punishment;

(b) violation of a human right, sufficiently severe to engage Member States' international obligations;

(c) a threat to his or her life, safety or freedom as a result of indiscriminate violence arising in situations of armed conflict, or as a result of systematic or generalised violations of their human rights.

The crucial issue therefore was the extent to which Article 15 reflected, developed or fell short of the international legal standard.

The Commission appeared confident that the Proposal basically represented the current situation:

19 Explanatory Memorandum, para 2, 4 .

${ }^{20}$ Council Directive 2003/86/EC of 22 Sept 2003 on the right to family reunification. This includes only family reunification of refugees recognized pursuant to the 1951 Convention and does not cover persons in need of subsidiary protection.

${ }_{21}$ An EU directive on this scheme of protection has been adopted, Council Directive $2001 / 55 / \mathrm{EC}$ of 20 July 2001 on minimum standards for giving temporary protection in the event of a mass influx of displaced persons and on measures promoting a balance of efforts between Member States in receiving such persons and bearing the consequences thereof, OJ L212, 7 Aug 2001, 12. On temporary protection see further J Fitzpatrick, 'Temporary Protection of Refugees: Elements of a Formalized Regime', 94 AJIL (2000) 279. 
No specific EU acquis directly related to subsidiary or complementary protection exists but the ECHR and the case law of the European Court on Human Rights provides for a legally binding framework, which informed the choice of categories of beneficiaries in this Proposal. The categories and definitions of persons listed in this Chapter do not create completely new classes of persons that Member States are obliged to protect but represent a clarification and codification of existing practice. The three categories . . . are drawn very much from the disparate Member State practices and are believed to encompass the best ones. ${ }^{22}$

The Commission appeared non-committal on the precise legal foundation for the establishment of the Article 15 obligation. In our view there is little doubt that at least part of Article 15 represented a codification of the existing legal situation. Even if all three criteria reflect existing State practice, as the Commission asserted, the question remains: to what extent is that practice based on obligation rather than goodwill alone?

\section{B. The Amended Proposal}

In the course of ongoing negotiation the Proposal was amended up to 19 June $2003 .{ }^{23}$ Some changes are significant, some more changes of emphasis rather than of substance. ${ }^{24}$ Of greatest significance for our purposes are the changes made with regard to entitlement to subsidiary protection. The original Proposal provided for subsidiary protection to be granted to aliens who, neither qualifying as refugees nor having applied for international protection on grounds that included the Geneva Convention, had a well-founded fear of suffering serious and justified harm for one of the three reasons set out in Article 15. The amended proposal is narrower. Article 2(e) describes as 'person eligible for subsidiary protection', a non-citizen

\footnotetext{
22 Above n 1, at 27-8.

23 Above $\mathrm{n} 12$

24 For instance, the definition of 'refugee' in the amended Proposal basically repeats the Geneva Convention definition. However, it finishes by stating that 'refugees' is restricted to people 'to whom Art 14 does not apply'. Art 14 contains the exclusion clauses found in Art 1 of the Geneva Convention but with some crucial additions. Thus Art 14(2)(b) excludes from protection those who have committed a serious non-political crime outside the country of refuge prior to admission as a refugee (as does the Geneva Convention). However, it continues: 'particularly cruel actions, even if committed with an allegedly political objective, may be classified as serious non-political crimes', hence excluding the perpetrators from protection. This reflects the changes in the international environment in the light of the attacks on the USA on 11 Sept 2001, the original Proposal having been published on 12 Sept 2001. However, the amended Proposal appears to go a step further in that the statement contained in the original, that States' obligations under international law to those excluded from refugee status continued to exist (Art 14(5)), does not appear in the new version. Instead, at Art $14 \mathrm{~B}(6)$, there is a statement that those excluded from refugee status are entitled to certain rights as set out (or similar to those set out in) in the Geneva Convention, including prohibition of refoulement. This may be narrower than the previous version, which referred to States' obligations under international law, rather than just the Geneva Convention. There is explicit acknowledgment of the principle of non-refoulement at Art 19.
} 
who does not qualify as a refugee but in respect of whom substantial grounds have been shown for believing that the person concerned, if returned to his or her country of origin, or in the case of a stateless person, to his or her country of former habitual residence, would face a real risk of suffering serious harm as defined in article $15 \ldots$

The amendments of Article 2(e) and Article 5 lead to two changes. First, by the deletion of Article 5(2) and the incorporation of this provision in Article 2(e), it seems that the amended Proposal no longer contains a State obligation to provide subsidiary protection if necessary. Article 2(e) only refers to persons 'eligible for subsidiary protection', whereas Article 5(2) provides for a State obligation to grant protection. This amendment was, on the other hand, ameliorated by Article 17B, which states that Member States shall grant subsidiary protection status to those who qualify as persons eligible for subsidiary protection in accordance with Chapters II and V. Secondly, it seems that the criterion for the risk assessment of future serious and unjustified harm the applicant may face once returned is more strictly defined. Whereas the Proposal in Article 5(2) mentioned the criterion of a 'well-founded fear', the new Article 2(e) refers to a 'real risk of suffering serious harm'. This riskcriterion is derived from jurisprudence from the European Court of Human Rights (ECtHR) on Article 3 ECHR and is understood to be stricter.

In defining the cases of serious harm Article 15 is much more specific than the corresponding provision in the original Proposal. This means that there is less scope for construing expansively the types of rights to be protected. It is also narrower. Revised Article 15 provides that:

Serious harm consists of:

(a) death penalty or execution; or

(b) torture or inhuman or degrading treatment or punishment of an applicant in his or her country of origin, or in the case of a stateless person, his or her country of former habitual residence; or

(c) serious and individual threat to a civilian's life or person by reason of indiscriminate violence in situations of international or internal armed conflict.

The amended provision retains the risk of torture or inhuman or degrading treatment or punishment from the original Proposal as a ground for subsidiary protection. However what is left is significantly circumscribed. Whereas the original Article 15 included violations of a human right, sufficiently severe to engage the Member State's obligations, the amended version refers only to the death penalty and execution. While the precise ambit of the previous formula was open to debate, it clearly referred to serious breaches of human rights. It contained room for a wider range of threats as giving entitlement to subsidiary protection, if not now then perhaps in light of subsequent practice and future development in jurisprudence of international tribunals.

The change to the third criterion is simultaneously more obvious and more 
drastic. Previously an entitlement to subsidiary protection arose where there was a threat to the 'life, safety or freedom' of the individual. Now the requirement is for a 'serious and individual threat' to a 'civilian's life or person'. There is no specific mention of safety or freedom, perhaps a weakening of the provision, although there may be room to argue that the reference to 'life or person' may be construed more expansively. Furthermore, apart from reducing the types of threat that are eligible, the reference to a 'serious and individual threat' would appear to require more in the way of the danger posed, thus raising the threshold, although it is arguable that the seriousness of the threat is in any case implied if it raises international protection obligations.

As for the source of the threat, it may now arise as a result of 'indiscriminate violence in situations of international or internal armed conflict'. As far as it goes this basically repeats the previous version. However, that version went further in that it also included threats arising as a result of systematic or generalised violations of the human rights of those affected. And this has simply vanished. It is quite possible to have systematic or generalised violations of human rights without an armed conflict taking place. Given that the first version of the Proposal was supposed to reflect the practice of the Member States (though clearly not all of them in all of its terms), it would appear that, unless some States modify their practice to bring it into line with the revised Proposal, they will be offering a more favourable regime than the rest. On the face of it that is not a problem, since the Proposal is supposed to establish minimum standards for the qualification for refugee status or subsidiary protection. However, should some Member States retain, and be seen to retain, a more liberal regime, they are likely to expose themselves to increased numbers of applications from persons seeking international protection. This would work against the EU's clear aim of having a common asylum policy with basically the same rules and standards applying across the Union. Another possibility is that Member States with more liberal regimes will scale them back until they are in conformity with the minimum standards.

So what does international law require in terms of subsidiary protection for those who do not qualify for refugee status? This question is addressed below.

III. THE NOTION OF SUBSIDIARY PROTECTION IN INTERNATIONAL LAW GENERALLY

The acknowledgment of the need for an alternative, subsidiary, or complementary protection ${ }^{25}$ scheme to the Geneva Convention reflects a debate of

\footnotetext{
25 These notions may be considered to cover the same persons in need of protection. In the context of the EU the term 'subsidiary protection' is used, whereas UNHCR prefers the use of the term 'complementary protection', underlining the complementarity of this scheme to the 1951 Convention.
} 
several decades in different fora. ${ }^{26}$ Although the UNHCR has long maintained that the Convention is broad enough to address all protection needs of refugees in the broader sense, ie falling under UNHCR's wider mandate, ${ }^{27}$ it is now well accepted that a subsidiary protection scheme is necessary. Already in 1951 the Final Act of the United Nations Conference of Plenipotentiaries on the Status of Refugees and Stateless Persons expressed

the hope that the $[1951$ Geneva] Convention ... will have value as an example exceeding its contractual scope and that all nations will be guided by it in granting so far as possible to persons in their territories as refugees and who would not be covered by the terms of the Convention, the treatment for which it provides. ${ }^{28}$

Since then there have been many calls for an additional instrument for those persons in need of protection.

Article 15 answers those calls by establishing a duty to grant subsidiary protection where the applicant for international protection has a well-founded fear of being subjected to one of three recognized categories of serious and unjustified harm. The issue is whether that answer goes far enough, or even too far, in the original version or the amended one. This part of the article considers the precise scope of each of these categories and the extent to which they are grounded on pre-existing obligations.

\section{A. Torture or Inhuman or Degrading Treatment or Punishment}

This was included in both versions of the Proposal and there is little doubt that the threat of exposure to such risks raises international protection obligations. The starting point for defining the scope of this subsidiary scheme is the human rights provisions of Article $3 \mathrm{ECHR}$, Article $3 \mathrm{CAT}$ and Article 7 ICCPR. ${ }^{29}$ For minors a special provision is laid down in Article 37(a) of the Convention on the Rights of the Child. ${ }^{30}$ Of these provisions, Article 3 ECHR has proven, over the years, to be the most effective basis for obtaining protection in individual cases. Article 3 ECHR contains an absolute guarantee of the rights it protects, including cases of expulsion. ${ }^{31}$ The protection afforded by

26 See, eg, nn 7 and 14; Recommendation (76) 773 Parliamentary Assembly of the Council of Europe, Resolution (84) 1; Report of Heinz Oskar Vetter, Doc. A 2-227/86/13 of 23 Feb 1987, OJ C 99, 167.

27 See Art 6 of the Statute of the Office of the UN High Commissioner for Refugees (GA Res $428(\mathrm{~V})$ of 14 Dec 1950). Over the years other categories of persons finding themselves in refugee-like situations have been brought under UNHCR's mandate by Resolutions of the ECOSOC and the General Assembly.

28 Recommendation E.

29 All EU Member States are parties to CAT. All are parties to the ICCPR; all except the UK are party to the First Optional Protocol; all except France are party to the Second Optional Protocol.

30 'States Parties shall ensure that: (a) No child shall be subjected to torture or other cruel, inhuman or degrading treatment or punishment ...'

31 Chahal v United Kingdom, 15 Nov 1996, 1996 V No 22, 23 EHRR 413; Ahmed v Austria, 17 Dec 1996, 1996 VI No 26, 24 EHRR 278. 
Article 3, as an implicit prohibition of refoulement, is thus wider than that provided by Articles 32 and 33 of the Geneva Convention, as these provisions stipulate exceptions to the principle of non-refoulement. Also, Article 3 ECHR does not require any link to one of the five protection grounds mentioned in Article 1 of the Geneva Convention. Article 3 ECHR cases have concentrated their judgments on the consequences of expulsion measures ${ }^{32}$ and have refrained from passing a judgment on possible implications on admission policies, except where it would amount to racial discrimination ${ }^{33}$ or where it involves frequent unsuccessful attempts at expulsion. ${ }^{34}$ This implies that parties, when considering an expulsion measure, have to take into account that they may act in breach of Article 3 ECHR by returning a person to a country where there are substantial grounds for believing that he faces a real risk of torture or inhuman or degrading treatment or punishment. Accordingly they must obtain all relevant information about the country of origin as well as specific information in relation to the person concerned. ${ }^{35}$ One limitation on States' obligations here is probably that there is no real risk of treatment contrary to Article 3 ECHR, if there exists an internal flight alternative within the country of destination. ${ }^{36}$

The case law of the ECtHR is rather clear about States' obligations where asylum seekers are at risk of suffering torture or inhuman or degrading treatment, should they be returned to the country from which they have sought asylum. While it is certainly the case that refugee status need only be granted to those who meet the Convention criteria, that does not mean that all those who fail to meet the criteria may be removed from the territory. Where there is a clear risk that the asylum seeker will be subjected to torture or inhuman or degrading treatment or punishment, the State may not remove the asylum seeker to that territory. This was confirmed in a string of cases during the 1990s.

The prohibition on removal of asylum seekers where there is a potential breach of Article 3 is actually an application of a broader rule, viz, that no one should be forcibly removed to a territory where he or she may be a victim of actions in breach of Article 3. The issue first arose before the ECtHR in the Soering case,${ }^{37}$ in which the Court found an 'inherent obligation' not to extradite where this might foreseeably lead to a breach of Article 3, and that this obligation extended 'to cases in which the fugitive would be faced in the receiving State by a real risk of exposure to inhuman or degrading treatment or punishment'. ${ }^{38}$ Where there were 'substantial grounds' for believing that the person concerned could be a victim of a breach of Article 3, then there was

\footnotetext{
32 Soering $v$ United Kingdom, A Series, No 138, 1988, 11 EHRR 439; Vilvarajah v United Kingdom, A Series, No 125, 1991, 14 EHRR 248; Ahmed v Austria, ibid.

33 Abdulaziz, Cabales and Balkandali v United Kingdom, A Series, No 94, 1985.

34 Giama v Belgium, No 7612/76, Bulus v Sweden, No 9330/81.

35 Assurances provided by the authorities of the receiving State where they depend on vagaries of diplomatic relations are considered not to be sufficient, Amuur v France, 22 EHRR 533.

36 Chahal $v$ United Kingdom, n 31, above.

37 Soering $v$ United Kingdom, n 32, above.

38 Ibid, at para 88.
} 
an obligation not to extradite, a decision in contradiction of which could engage the responsibility of the State. ${ }^{39}$

The restriction placed by Article 3 on States' freedom of action includes situations where the threatened breach of Article 3 is posed by non-State actors and the State is unable to prevent such action. In HLR v France, ${ }^{40}$ it was held that (where the applicant was challenging deportation to Colombia because of threats allegedly posed by drug traffickers there), "where the danger emanates from persons or groups of persons who are not public officials', deportation to that territory could breach Article 3 'where the risk is real and ... the authorities of the receiving State are not able to obviate the risk by providing appropriate protection' ${ }^{41}$

The restriction was extended even further in $D v$ United Kingdom $^{42}$ to include cases where there is no deliberately inflicted act that breaches Article 3 , but rather an inability of the State to provide basic facilities that would prevent the individual at risk from being reduced to living in circumstances that could be construed as inhuman or degrading treatment, should he or she be removed to that State. The Court held that deportation would in fact breach Article 3, even though there was no suggestion that the applicant was at risk from any intentionally inflicted act either by the authorities or non-State bodies in the country (St Kitts): rather, the threat posed was more one of the inability of the State to provide basic facilities to sustain the applicant. ${ }^{43}$

The de facto protection against deportation provided by Article 3 applies to anyone who faces a real risk of being a victim of its breach, and in several cases this has operated for the benefit of asylum seekers whose claims, based on the Geneva Convention, have failed. In two cases, Cruz Varas $v$ Sweden ${ }^{44}$ and Vilvarajah and Others $v$ United Kingdom, ${ }^{45}$ the Court acknowledged the principle that because of the risks to which they were exposed in the countries to which they would be deported, it could amount to a breach of Article 3 to deport asylum seekers whose claims had been rejected. However, in each case it was held on the facts that there was no such breach. In Chahal $v$ United Kingdom ${ }^{46}$ the Court was faced with the proposed deportation of an asylum seeker to India. It stressed its 'well-established' case law that expulsion may give rise to a possible breach of Article 3 and that, in such a situation, where there were substantial grounds for believing that the expelled person faced a real risk of being a victim of treatment contrary to Article 3 in the receiving country, then Article 3 implied an obligation not to expel the person to that country. ${ }^{47}$ Consequently the asylum seeker was permitted to remain in the UK. This reasoning was also applied in Ahmed $v$ Austria. ${ }^{48}$

\footnotetext{
39 Ibid, at para 91. $\quad 40$ HLR v France 26 EHRR 29.

42 D v United Kingdom, 24 EHRR 423.

41 Ibid, at para 40

44 Cruz Varas $v$ Sweden 14 EHRR 1.

45 Vilvarajah and Others $v$ United Kingdom, n 32, above.

46 Chahal v United Kingdom, n 31, above.

43 Ibid, para 49

48 Ahmed v Austria, n 31, above.
} 
In none of these cases is it suggested that the defendant State was itself likely to commit a direct breach of Article 3. The liability was indirect, founded upon the responsibility of the State should it be the cause of the individual being sent to a territory where he or she would be the victim of a breach. ${ }^{49}$ That risk is enough to oblige the State to let the individual remain.

Each of these decisions emphasizes that Article 3 enshrines fundamental values of democratic societies, and prohibits torture or inhuman and degrading treatment or punishment in absolute terms. No derogation from Article 3 is ever permissible. Furthermore they establish that the obligation not to place anyone in a situation where there is a reasonable likelihood that they will suffer a breach of Article 3 extends to possible breaches perpetrated by nonState actors, and even to breaches that occur not because of some deliberate positive action against the individual, but because the conditions in the territory to which the person is returned mean that they are likely to become victims of a breach.

What actually constitutes torture or inhuman or degrading treatment or punishment depends on all the circumstances of the case, such as the nature and context of the treatment or punishment, the manner and method of its execution, its duration, its physical or mental effects, ${ }^{50}$ the sex, age, and state of health of the victim. ${ }^{51}$ The Court has repeatedly underlined that the ECHR is a living instrument ${ }^{52}$ and that the judgment of what constitutes a breach of Article 3 ECHR should be based upon present day conditions. ${ }^{53}$ Importantly, in the light of State practice in some countries that rule out breaches of Article 3 ECHR emanating from non-State entities, ${ }^{54}$ the Court has explicitly stated that it is not necessary that the measure resulting in a breach of Article 3 ECHR be taken by central State authorities. Also, acts by private persons, guerillas, or parties involved in a civil conflict can be relevant ${ }^{55}$ In these cases a question arises as to whether the authorities in the country of destination are capable of offering protection against such acts. ${ }^{56}$

\footnotetext{
49 Soering v United Kingdom, n 32, above, para 91: 'the decision by a Contracting State to extradite a fugitive may give rise to an issue under Article 3 , and hence engage the responsibility of that State under the Convention, where substantial grounds have been shown for believing that the person concerned, if extradited, faces a real risk of being subjected to torture or to inhuman or degrading treatment or punishment in the requesting country ... In so far as any liability under the Convention is or may be incurred, it is liability incurred by the extraditing Contracting State by reason of its having taken action which has as a direct consequence the exposure of an individual to proscribed ill-treatment.'

${ }^{50} \mathrm{D} v$ United Kingdom, $\mathrm{n} 42$, above.

51 Ireland $v$ United Kingdom, Series A No 25, 65, para 162; and Tyrer v UK, Series A No 26, 14-15, paras 29 and 30, Soering $v$ United Kingdom, n 32 above, para 100.

52 Ibid, para 102.

53 Ibid, para 104.

54 See, for examples: German Federal Administrative Court decisions of 17 Oct 1995, 9 C 15.95, EZAR 043, No 11; 9 C 56.95, InfAuslR 1996, 254 and 4 June 1996, 9 C 134.95, InfAuslR 9/1996, 289.

55 Ahmed v Austria, n 31, above; see also European Commission on Human Rights: Altun v FRG (No 100308/83), Kirkwood v United Kingdom (No 10478/83).

56 Chahal v United Kingdom, n 31, above; Ahmed v Austria, n 31, above.
} 
The Committee Against Torture has in several cases considered whether expulsion may be in breach of Article 3 CAT. Generally speaking this provision covers to a great extent the same cases, although it can be argued that the Committee requires a less strict standard to the risk criterion than the ECHR. ${ }^{57}$ The Committee stated that the aim is to establish whether the individual concerned would be personally at risk of being subjected to torture in the country to which he would return. The existence of a consistent pattern of gross, flagrant or mass violations of human rights does not as such constitute a sufficient ground for determining that a person would be in danger of being subjected to torture upon return; additional grounds must exist that indicate that the individual concerned would be personally at risk. Conversely, the absence of a consistent pattern of gross, flagrant or mass human rights violations does not mean that a person cannot be considered to be in danger of being subjected to torture or other treatment prohibited by Article 3 CAT upon return in his specific circumstances. ${ }^{58}$ Even if the facts adduced by the author are not coherent, the Committee reiterated the ratio of Article $3 \mathrm{CAT}$, that it should be certain that the individual's safety is not endangered. In this case the Committee noted that a late submission of claims and corroboration was not uncommon for victims of torture. Also, the Committee took account of a submitted medical report that did not contradict the applicant's allegations. ${ }^{59}$ The risk to which the individual would have to be exposed has been described as 'foreseeable, real and personal' ${ }^{60}$

Decisions based upon Article 7 ICCPR are less developed. It must also be remembered that the Human Rights Committee, although generally consisting of lawyers, is not a court; nor does it make decisions binding upon the parties. ${ }^{61}$ The Committee has interpreted Article 7 thus:

57 The CAT Committee applies among others within the risk assessment the standard of 'beyond mere theory or suspicion'. It does not have to meet the test of being highly probable, see: General Comment on the implementation of Art 3, A/53/44, Annex IX, para 6. Affirmed in $A S v$ Sweden, Communication No 149/1999, (2001) 8 International Human Rights Reports 970, para 4.4; and MRP v Switzerland, Communication No 122/1998, (2001) 8 International Human Rights Reports 967, para 6.4.

58 Mutombo $v$ Switzerland, Communication No 13/93, para 9.3., <http://www1.umn.edu/ humanrts/cat/decisions/catD-Switzerland94.htm>, $A M v$ Switzerland, Communication No 144/1999, (2002) 9 International Human Rights Reports 36, para 6.3 and GT v Switzerland, Communication No 137/1999, (2002) International Human Rights Reports 40, para 6.3.

59 Tahir Houssain Khan $v$ Canada, Communication No 15/1994. para 12.3. $<\mathrm{http}: / /$ www1 .umn.edu/humanrts/cat/decisions/catD-Canada1.htm>.

${ }^{60} A S v$ Sweden, $\mathrm{n} 57$, above, para 4.4; MRP $v$ Switzerland, $\mathrm{n} 57$, above, para 6.5 .

61 The Committee itself has said that it is neither a court nor a body with a quasi-judicial mandate, like the organs created under another international Human Rights instrument, the European Convention on Human Rights. ... Still, the Committee applies the provisions of the Covenant and the Optional Protocol in a judicial spirit and performs functions similar to those of the [former] European Commission of Human Rights, in as much as the consideration of applications from individuals is concerned. Its decisions on the merits . . . are, in principle . . . non-binding recommendations' (1990) 2 Selected Decisions HRC 1-2. 
2 ... the scope of protection required goes far beyond torture as normally understood. It may not be necessary to draw sharp distinctions between the various prohibited forms of treatment or punishment. These distinctions depend on the kind, purpose and severity of the particular treatment. In the view of the Committee the prohibition must extend to corporal punishment, including excessive chastisement as an educational or disciplinary measure. Even such a measure as solitary confinement may, according to the circumstances, and especially when the person is kept incommunicado, be contrary to this [A]rticle. Moreover, the article clearly protects not only persons arrested or imprisoned, but also pupils and patients in educational and medical institutions. Finally, it is also the duty of public authorities to ensure protection by the law against such treatment even when committed by persons acting outside or without any official authority. ${ }^{62}$

This statement demonstrates a flexible approach, focusing less on whether a particular act is torture rather than some other form of prohibited treatment, and more on the particular way in which an individual has been treated. But the Committee does not appear to have extended the ambit of Article 7 beyond the types of treatment that would have been covered also by Article 3 ECHR.

The notion of inhuman or degrading treatment, which under the ECtHR has been gradually expanded, has already been interpreted by the Committee sufficiently generally as to suggest rather wide scope, but also as sufficiently serious, it is suggested, as to justify activating international protection obligations should the person at risk apply for protection. In Vuolanne $v$ Finland, the Committee stated:

the assessment of what constitutes inhuman or degrading treatment falling within the meaning of Article 7 depends on all the circumstances of the case, such as the duration and manner of the treatment, its physical or mental effects as well as the sex, age and state of health of the victim. ${ }^{63}$

There was a level of humiliation or debasement to be exceeded before a particular treatment or punishment could be considered degrading. ${ }^{64}$ Thus once the threshold had been crossed, there could be a breach of Article 7, but that threshold might vary from person to person.

Complaints made under Article 7 have been concerned with past breaches rather than the risk of future breaches in the event of return. Nevertheless the practice of the Human Rights Committee helps to clarify the types of threat that would activate protection obligations.

${ }^{62}$ General Comment 7, 30 Apr 1982, website of the UN High Commissioner for Human Rights, <http://193.194.138.190/tbs/doc.nsf>. General Comment 20 of 10 Mar 1992, which is intended to reflect and further develop General Comment 7, confirms this approach: '4. The Covenant does not contain any definition of the concepts covered by Art 7, nor does the Committee consider it necessary to draw up a list of prohibited acts or to establish sharp distinctions between the different kinds of punishment or treatment; the distinctions depend on the nature, purpose and severity of the treatment applied.'

${ }^{63}$ Comm No 265/1987; 196 ILR 649, para 9.2.

${ }^{64}$ Ibid. 
Generally speaking then, the scope of Article 7 ICCPR is similar to that of Articles 3 ECHR and CAT, although the wording of Article 7 ICCPR is slightly different, adding the word 'cruel'. In order to codify all international treaty obligations into the Proposal it would therefore have been desirable to add the word 'cruel' into Article 15 (a) in the original Proposal. This has not been done.

In conclusion, the obligation of Member States to refrain from returning a person to a third country, arising out of the above international instruments, can be summarized as follows: if there are substantial grounds for believing that a person would be subjected to torture or inhuman or degrading treatment in the State to which they are to be sent (or indeed in a third country if indirectly expelled), ${ }^{65}$ the decision is tantamount to an infringement of Article 3 ECHR, Article 3 CAT or Article 7 ICCPR by the country expelling the person. The reasons why an individual may face such a risk are basically irrelevant to the question of protection under these provisions.

The following types of cases are covered:

- Persons eligible for refugee status based on the Geneva Convention, but who are exempted under one of the exclusion clauses.

- Persons who may face measures contrary to Article 3 ECHR, CAT, (or 7 ICCPR) in the country to which they will be expelled, emanating from the central authority or other groups or individuals.

The cases indicate that the following measures, among others, ${ }^{66}$ may amount to inhuman or degrading treatment or punishment:

- Depending on the circumstances of the case, persons who will be subjected to death row phenomenon awaiting the execution of the death penalty in the country to which they will be expelled.

- Persons who are frequently subjected to unsuccessful attempts at expulsion or persons in orbit. ${ }^{67}$

- Persons who are refused admittance to the territory as a result of racial discrimination. ${ }^{68}$

- Persons who are infected with HIV and who may be deprived of adequate medical care if expelled, which would amount to physical suffering.

65 Expulsion to a third country in which the person concerned faces being further returned to a country where he may face treatment contrary to Art 3 ECHR is also relevant in this respect, TI $v$ United Kingdom, No 43844/98.

66 In national jurisprudence, including in The Netherlands and Germany, a further elaboration of measures can be found which are considered to be inhuman or degrading, such as genital mutilation of women, forced sterilization or abortion as a result of the State's policy on birth control and sexual violence against women. Some of these human rights violations may be considered to be covered by the 1951 Geneva Convention.

67 Harabi v The Netherlands, European Commission on Human Rights, No 10798/85, DR, 1986. 116.

68 East African Asian Cases, European Commission on Human Rights, No 4403/70, YBECHR 13,928 . 
- Persons facing normal punishment for an offence according to the legislation of the country concerned, where this punishment is arbitrary, discriminatory, cruel or excessive. ${ }^{69}$

The international instruments and jurisprudence outlined above provide for protection against expulsion. However, they do not imply any obligation of parties to grant any specific residence permit or rights to the person concerned.

An issue arises as to whether State responsibility exists for indirect refoulement. If there is a reasonable likelihood that another State will itself cause the asylum seeker to be sent to the territory where the risk of being treated in breach of Article 3 exists, would the obligation to permit an individual to remain on the territory extend to such situations? The ECtHR has not addressed this directly. However, its reasoning in the Article 3 cases offers guidance. What the Court did in these cases was to focus on the responsibility of the State for placing the individual in a situation where they were likely to become victims of treatment which would be in breach of Article 3 were it to take place in the respondent State. Since in each case the individual was physically present in the respondent State and therefore subject to its jurisdiction; since furthermore the proposal was to return the individual against their will to their State of nationality (the only State obliged under international law to permit entry) where they faced the risk of being subjected to treatment in breach of Article 3, effectively the returning State was placing the individual at risk.

With indirect refoulement, where the individual is returned to a safe third State (safe in as much as that State will not itself expose the individual to treatment in violation of Article 3) but one that may be expected to in turn return the asylum seeker to a territory where they are at risk, there is clearly room to argue that the responsibility of the first returning State is engaged for having exposed the asylum seeker to that risk. The UK courts have long accepted that an individual may not be returned to a territory which is itself safe, if there are reasonable grounds for believing that the authorities there will simply pass the person onto a territory where they are likely to suffer persecution. ${ }^{70}$ On this basis the UK courts have declined to authorise return of asylum seekers to France and Germany, neither of which recognised persecution by non-State actors as raising an entitlement to asylum. ${ }^{71}$

\footnotetext{
${ }^{69}$ In national case law more examples can be found, in particular on punishments under the Sharia, such as lashing or the amputation of parts of the body. Prison conditions in certain countries, where physical violence among the detainees is common and where there is a lack of provision of basic human needs, have also been considered inhuman or degrading.

70 Re Musisi [1987] AC 514.

71 In the UK this protection includes a prohibition on return to third States that do not interpret the Refugees Convention as broadly as the UK, so that someone who would have been allowed to remain in the UK (for instance because of persecution by non-State actors) but could be removed to a third State to seek asylum there, could not be removed to that State if it would itself return the asylum seeker to their home State because of not recognizing persecution by non-State actors as sufficient to qualify for asylum: $R v$ Secretary of State for the Home Department, ex parte Adan, $R v$ Secretary of State for the Home Department, ex parte Aitsegur [2001] 1 All ER 593.
} 
In this context, the issue is not whether a State recognizes persecution by non-State actors as raising an entitlement to refugee status. Rather, it is a matter of whether the risk of the individual suffering treatment in breach of Article 3 ECHR as a consequence of indirect refoulement obliges the State not to remove that person (who may be a refugee). Given the absolute nature of the prohibition on torture and inhuman and degrading treatment, which has been stressed repeatedly by the ECtHR, ${ }^{72}$ and the obligation, stated by the Court, not to cause individuals to be exposed to a real risk of such treatment, it is logical, in keeping with the spirit of the Court's rulings, and in line with the reasoning of the UK courts, to extend subsidiary protection to those at risk of being subjected to breaches of Article 3 as a result of indirect refoulement. This was the precise recommendation of the Human Rights Committee in AS $v$ Sweden. ${ }^{73}$

\section{B. Violation of a Human Right, Sufficiently Severe to Engage Member States' International Obligations-Death Penalty or Execution}

The original Proposal suggested an entitlement to subsidiary protection where the individual has a well-founded fear of being the victim of a violation of their human rights sufficiently severe as to engage the international obligations of the relevant Member State. The revised Proposal replaced this with a new Article 15(a) that lists the death penalty or execution as harm serious enough to qualify the applicant for subsidiary protection should he or she show a real risk of being exposed to serious harm. The issue therefore arises whether the revised provision meets Member States' obligations, or whether the wider, original version more closely reflected the legal position. Given that the original Proposal was said to reflect existing practice, there has certainly been on the face of it a retreat, although that is not to say that the practice was entirely based on international obligations. The issue therefore is: which violations are sufficiently severe as to give rise to international protection obligations? Here it will be considered whether there exist other provisions in human rights treaties that may amount to an obligation of parties to refrain from expulsion measures.

The death penalty is not necessarily a breach of human rights. Its legitimacy (subject to certain provisos) is recognized in the $\operatorname{ICCPR}^{74}$ and the

72 See, for instance, $D$ v $U K, \mathrm{n} 42$, above, para 47: 'in exercising their right to expel . . . aliens Contracting States must have regard to Art $3 \ldots$ which enshrines one of the fundamental values of democratic societies. It is precisely for this reason that the Court has repeatedly stressed in its line of authorities involving extradition, expulsion or deportation of individuals to third countries that Art 3 prohibits in absolute terms torture or inhuman or degrading treatment or punishment and that its guarantees apply irrespective of the reprehensible nature of the conduct of the person in question.'

73 'The State party has an obligation, in accordance with Art 3 of the Convention, to refrain from forcibly returning the author to Iran or any other country where she runs a risk of being expelled or returned to Iran.' Above n 57, para 9.

74 Art 6(2). 
ECHR. ${ }^{75}$ However, each of these instruments has been supplemented by optional protocols, the effect of which is to outlaw the death penalty. In EU Member States expulsion is now prohibited where there is the risk of the death penalty in the country of destination. Although the ECtHR has not as such prohibited expulsion in cases in which the person in question faces the death penalty, ${ }^{76}$ all Member States of the European Union have however signed up to the 6th Protocol to the ECHR on the abolition of the death penalty, prohibiting both the levying and execution of such penalty. ${ }^{77}$ All except France are parties to the Second Protocol of the ICCPR, which has the same objective. The effect is that a person may not be expelled from an EU Member State to a country where he or she faces the risk of the death penalty.

The inclusion of the death penalty and execution as serious harms giving rise to subsidiary protection obligations therefore falls comfortably within the current scope of Member States' duties. The issue however remains whether the revised provision actually goes far enough. In other words, are there other human rights, violation of which would be sufficiently severe to activate Member States' obligations? If there are, then even full adherence to Article 15 might not be enough to keep them within the law.

In its Explanatory Memorandum to the original Proposal, the Commission stressed that subsidiary protection was to be granted to those who had a 'well founded fear of (suffering) ... serious (unjustified) harm' ${ }^{78}$ The Commission explained this formula thus:

The term 'unjustified' is added to the definition of 'serious harm' in order to reflect that there are circumstances in which a state may be justified in taking measures that cause harm to individuals, such as in the event of a public emergency or national security. Such instances of 'justified' harm are likely to be rare but it would be contrary to human rights instruments . . . to exclude the possibility that some proportionate derogation from human rights standards may, in limited and particular circumstances, be justified, most commonly in the interests of the wider common good. ${ }^{79}$ (emphasis in the original)

This suggests that there might be no entitlement to subsidiary protection where the potential threat or harm to the applicant is justified as a derogation from the ECHR since that will be a legitimate act of the State-even though it clearly may be harmful to the individual. It must however be recognized that derogation is permitted only in exceptional circumstances and only to the extent justified in the exigencies of the particular situation. Most applicants for

\footnotetext{
75 Art 2(1)

76 Soering $v$ United Kingdom, n 32, above. Interesting in this respect is the personal opinion of Judge De Meijer, stating that the court ruling does not reflect the current legal position in Western Europe, EUGRZ 1989, S. 314 (326).

77 European Treaty Series, no 114, 28 Apr 1983.

78 Above $\mathrm{n} 1$, at 14.

79 Ibid, at 14-15.
} 
subsidiary protection are unlikely to be complaining of risks that would be justified by the State on the basis of public emergency or national security. Two further issues arise out of this:

- the possible consequences of breaches of the non-derogable human rights; and

- the scope of serious and unjustified harm beyond the non-derogable rights and the consequences of their breach.

\section{Non-derogable Human Rights}

The emphasis on permissible harms (in the context of public emergency or threat to national security) inevitably draws attention to the non-derogable provisions of the ECHR. It is surely arguable that these rights are so fundamental that any individual who is faced with a possible breach of such rights in the event of refoulement may have a legitimate claim to subsidiary protection.

Article 15 ECHR allows derogations in limited circumstances from most of the rights guaranteed. But derogation is never permitted with regard to Article 2 (right to life-except in respect of deaths resulting from lawful acts of war), Article 3 (prohibition of torture and inhuman or degrading treatment or punishment), Article 4(1) (prohibition of slavery or servitude) and Article 7 (no punishment without law). Articles 2 and 3 are already included within the scope of Article 15 (either version). But what about Articles 4(1) and 7? We would suggest that the risk of slavery or servitude should a person be returned to their State of citizenship or residence easily constitutes 'serious unjustified harm', to use the Commission's own terminology. ${ }^{80}$ It is also likely that slavery or servitude might also be inhuman or degrading treatment, which would bring the individual within the scope of Article 15 by another route.

Article 4(1) provides: 'No one shall be held in slavery or servitude.' This has not really been much of an issue in Council of Europe States until the collapse of communism. ${ }^{81}$ The real threat here is that posed by the trafficking of human beings in EU Member States, against which governments are unable or unwilling to offer effective protection.

The threat posed by the crime of people trafficking to the fundamental

\footnotetext{
80 Para 53 (4) of the German Aliens Act for example is meant to incorporate all relevant provisions of the ECHR - and not only Art 3-which may give rise to non-expulsion of an applicant to a country that may act in breach of these provisions, BT-Drucks. 11/6321, 75 .

81 There is also evidence of the relevance of this provision in Dutch case law, concerning an applicant belonging to the black population in Mauritania, who faced the risk of being enslaved after return. Although slavery has been formally abolished several times in Mauritania, it still exists: Rb Zwolle, 11 Mar 1997, Nieuwsbrief Asiel en Vreemdelingenrecht 1997, No 4, S. 336. In German case law, return to Laos of an applicant to face the risk of forced labour in a 'resocialisation' camp for alleged dissidents was considered under Art 4(2) ECHR, VG Ansbach, 2 Jan 1997, AZ: AN 12 K 95.33534. In this case one may assume that the alleged risk may be also relevant under the Geneva Convention.
} 
rights of its victims is well recognised, both at international law ${ }^{82}$ and within the EU system. ${ }^{83}$ The EU has recognized that people trafficking is not only an immigration issue (although it tends to be categorized as such) but a serious crime that poses grave threats to basic human rights. ${ }^{84}$ It is hard to see, therefore, why slavery and servitude (of which people trafficking is in many cases a contemporary example) are excluded, or even can be excluded, from the subsidiary protection regime if that regime is to reflect the existing obligations of the Member States.

The seriousness of the crime of people trafficking is also reflected in the fact that, in certain cases, it will be treated as a war crime or crime against humanity: $: 55$ offences sufficiently serious that there is individual criminal responsibility for them at international law. Once one adds this to the nonderogability of Article 4(1) of the ECHR, it becomes increasingly difficult to see how anyone who is at serious risk of being subjected in their home State to harm that would breach that provision could not be entitled to some form of international protection.

82 Protocol to Prevent, Suppress and Punish Trafficking in Persons, Especially Women and Children, supplementing the United Nations Convention against Transnational Organised Crime (2000) (A/55/383) requires parties, inter alia, to consider permitting victims of trafficking to remain on their territory in cases where requiring the victim to return to the home State may give rise to a real threat of danger or harm to her (Art 7(1)).

83 Treaty on European Union, Art 29; Vienna Action Plan, Dec 1998, paras 18 and 46; Tampere European Council, 15-16 Oct 1999, Presidency Conclusion No 23; Laeken European Council, 14-15 Dec 2001, Conclusion No 42; Council Framework Decision of 19 July 2002 on combating trafficking in human beings (especially Preamble, para (3), OJ L 203; Proposal for a comprehensive plan to combat illegal immigration and trafficking of human beings in the European Union, 14 June 2002, 2002/C 142/02. The Proposal (at para 11) specifically referred to the need to balance the right to decide whether to accord or refuse admission to third country nationals and the obligation to protect those genuinely in need of international protection. Para 11 then specified that this concerned 'in particular, obligations for protection arising from the European Convention on Human Rights, particularly Art 3 thereof, and the Geneva Convention on Refugees, most notably Arts 33 and $31^{\prime}$. This might be said to support the notion that subsidiary protection should not be extended beyond those who are covered by these provisions. However, there is another and, it is suggested, better, way to look at it: Art 3 ECHR and Arts 31 and 33 of the Geneva Convention are picked out but they are not said to be exclusive. The term used is 'in particular', suggesting that other parts of those treaties may be relevant here. If that is the case, then surely the most immediately relevant rights would be those which are so fundamental that no derogation from them is permissible. The joint IOM/EU Brussels Declaration on Preventing and Combating Trafficking in Human Beings (Sept 2002) also acknowledges the human rights dimension. Finally, the Proposal for a Council Directive on the short-term residence permit issued to victims of action to facilitate illegal immigration or trafficking in human beings who cooperate with the competent authorities, published in Feb 2002 (COM (2002) 71 final), goes some way, especially at Art 4, to recognising the possible need of victims of trafficking for international protection. For detailed commentary see R Piotrowicz, 'European Initiatives in the Protection of Victims of Trafficking who Give Evidence Against Their Traffickers' 14 International Journal of Refugee Law (2002) 263-78.

${ }_{84} \mathrm{See}$, in particular, the joint IOM/EU Brussels Declaration on Preventing and Combating Trafficking in Human Beings (2002), ibid.

85 Statute of the International Criminal Court, Arts 8(2)(b)(xxii) and 7(c) and (g), 37 International Legal Materials (1998) 999. See also Prosecutor v Kunarac, Kovac and Vukovic, Case No IT-96-23-T and IT-96-23/1-, Judgment of 22 Feb 2001, para 542, International Criminal Tribunal for the Former Yugoslavia. 
Similar considerations apply with regard to Article 7 ECHR, incorporating the principle of legality, which prohibits holding anyone guilty of a criminal offence on account of any act or omission that was not a criminal offence under national or international law at the time of commission. It also prohibits imposition of a heavier penalty for a criminal offence than was permitted at the time the offence was committed. There have been very few cases alleging breaches of Article 7. However we suggest that where a person can show that he or she is at serious risk of being a victim of such a breach, then that should give rise to protection obligations.

It is very difficult to envisage a situation in which EU Member States - all parties to the ECHR - say, on the one hand, that slavery and servitude are so evil that it is never permissible to derogate from their prohibition, yet on the other hand not regard them as a harm sufficiently serious to be included within the scope of Article 15 of the Proposal.

\section{Serious and unjustified harm beyond the scope of the non-derogable rights}

The second issue concerns the types of threat or danger covered by the requirement for serious and unjustified harm. While it may allow a certain leeway where the threat to the individual is in the context of national emergency or threat to the nation, the requirement cannot of itself exclude the possibility that, in the absence of such threat to the nation (and derogation situations are rare), a serious risk of breach of some other human right (ie, not the death penalty or execution) may give rise to protection obligations (as suggested by the original Proposal but not by the revised one).

There have been few decisions on the other provisions in the context of international protection. The ECtHR ruled in Soering $v$ United Kingdom that:

Article 1 cannot be read as justifying a general principle to the effect that notwithstanding its extradition obligations, a Contracting State may not surrender an individual unless satisfied that the conditions awaiting him in the country of destination are in full accord with each of the safeguards of the Convention. ${ }^{86}$

However, that did not mean that the convention had no relevance. The court stressed that such considerations could not absolve the parties from responsibility under Article 3 ECHR 'for all and any foreseeable consequences of extradition suffered outside their jurisdiction' ${ }^{87}$ Clearly then there were limits to parties' human rights obligations, but these could certainly extend to include some responsibility for those whom they sent to a territory where certain of their human rights would be breached. The absolute prohibition on torture and inhuman or degrading treatment or punishment was a relevant factor here: the seriousness of any breach of such rights was such that the obligations of the parties extended beyond their treatment of the individual

\footnotetext{
86 Above n 32, para 86. $\quad 87$ Ibid.
} 
while he or she was in their jurisdiction. There is no coherent justification why the same reasoning should not apply to all of the non-derogable rights in the ECHR.

But there may be scope to go further. In Soering, the court ruled that it 'does not exclude that an issue might exceptionally be raised under Article 6 by an extradition decision in circumstances where the fugitive has suffered or risks suffering a flagrant denial of a fair trial in the requesting country': ${ }^{88}$ not every denial of a fair trial would necessarily amount to an obligation of Member States to refrain from expulsion, but such obligation could arise where the potential violation reaches a certain level of magnitude or seriousness: where there is a 'flagrant denial'.

The ECtHR considered the competing interests of State and claimant again in Bensaid $v$ United Kingdom. ${ }^{89}$ In that case the UK wished to remove an Algerian citizen who suffered from a severe mental illness. He argued that his removal would be a breach of Articles 3 and 8, the right to respect for family and private life. The court reiterated that Article 3 imposed a protection obligation on States where the removal of the individual gave rise to a risk of its breach, although it did stress 'the high threshold set by Article 3, particularly where the case does not concern the direct responsibility of the Contracting State for the infliction of harm,${ }^{90}$ On the facts it found that removal would not breach Article 3.

With regard to Article 8, the applicant had argued that his removal to Algeria would cause serious adverse harm to his mental health, which would constitute an interference with his right to private life. The court accepted that mental health must be accepted as a crucial part of private life. ${ }^{91}$ However, it found that even if the applicant's removal could be said to be a dislocation sufficient to interfere with his Article 8 rights, that could nevertheless be justified, under Article 8(2), as a measure 'in accordance with the law', to pursue protection of the economic well-being of the country and the prevention of disorder and crime, and 'necessary in a democratic society' for those aims. ${ }^{92}$ So, there is a clear limitation here. Article 8(2) allows substantial scope to the State to remove aliens even if there is a threat to their rights in the country to which they would be removed.

In such cases it is hard to see a justification for arguing that the individual should be entitled to subsidiary protection. The scope of Article 8 is as such not linked to the need of protection against human rights violations that the applicant may suffer in the country to which he will be returned.

88 Ibid, para 113. This is supported by the decision of the ECtHR in Drozd and Janousek $v$ France and Spain (1992) 14 EHRR 745, at para 110. The Court stated that the ECHR does not require parties to impose their standards on other States; accordingly the possible breach of the individual's right by a third State did not necessarily give rise to protection obligations (we are not dealing here with non-derogable rights). However the parties are 'obliged to refuse their cooperation if it emerges that the conviction is the result of a flagrant denial of justice'.

89 (2001) 33 EHRR 10

90 Ibid, para 40. $\quad 91$ Ibid, para 47. $\quad 92$ Ibid, para 48. 
Harmonisation of EU policy and legislation on family reunification is being provided for in a separate directive. ${ }^{93}$

There is no justification, on the basis of ECtHR case law, for an obligation to allow aliens to remain in the absence of a serious risk of a breach of one of the non-derogable rights, or else perhaps a threat of a flagrant violation of another convention right. Although the court has recognised the possibility of the risk of such flagrant violation giving rise to protection obligations on the part of parties, it has yet to find it in practice. Despite the oft-repeated mantra that the Convention is a living instrument (which in itself explains the extension of Article 3 in Soering and subsequent cases), the Court has made it clear that the Convention does not require parties to ensure that all Convention rights be available to an individual in the State to which it intends to remove that individual.

The notion of a flagrant denial of the individual's rights in the country to which the State party to the ECHR wishes to remove the person as possibly raising protection obligations, has been recognised recently in several British cases, even where the right concerned is a derogable one. However, the courts have stressed the limited scope of such obligations, particularly recognising that there is a legitimate interest on the part of the State in exercising effective immigration control, an interest that does not give way to the human rights claim.

Thus, in $R$ (Holub and another) $v$ Secretary of State for the Home Department ${ }^{94}$ concerning whether the proposed expulsion of a child in fulltime education in the UK would be a breach of the right to education under Article 2 of the first protocol of the ECHR, the Court of Appeal held that this right was a limited social right that did not include a right to remain after the State, in exercising its immigration control, had refused leave to remain. It stated that the ECtHR's jurisprudence 'does point clearly to the fact that rights which are not absolute, such as the right to education, are not engaged where a state is exercising legitimate immigration control' .95

In Devaseelan v Secretary of State for the Home Department ${ }^{96}$-possible breach of Articles 5 and 6 ECHR were a Tamil to be returned to Sri Lankathe Tribunal stressed that the ECHR was not a general tool to be used by aliens fighting their removal: the possibility of a breach of their rights did not engage the expelling State's obligations. ${ }^{97}$ The Tribunal repeated that the returning State would only have duties under the ECHR with regard to Article 3, or else 'so extreme a breach of another Article' that the returning State would have to have regard to the consequences of return. This could only arise if there would be a 'flagrant denial or gross violation of the rights secured by the Convention'. ${ }^{98}$ $\begin{array}{ll}93 & \text { Above n } 20 . \\ 96 & 94 \text { [2001] } 1 \text { WLR } 1359 . \\ \text { [2002] UKIAT 00702. } & 97 \text { Ibid, para } 107 .\end{array}$
95 Ibid, para 21.

98 Ibid, para 110. 
In $R$ (Ullah) $v$ Secretary of State for the Home Department ${ }^{99}$ the High Court held that Article 9 (freedom of thought, conscience and religion) could have only very limited impact in expulsion cases:

the most that can be expected of the court in an expulsion case such as this, involving an alleged breach of [A]rticle 9 in the receiving state, is to consider whether there would be a flagrant denial of the right of manifestation of religion, in the same way as the court has to consider whether there would be a flagrant denial of the relevant right by the receiving state in [A]rticle 6 cases. ${ }^{100}$

The flagrant denial of a right was the absolute minimum required before it would be possible to consider whether a State's ECHR obligations were engaged. This recognises the exceptional nature of such a situation and acknowledges the legitimate interest of States in having effective immigration control. The judge also said, obiter, that effective immigration control would be a legitimate reason, under Article 9(2), for a State to remove an alien even where that would result in a (non-flagrant) violation of Article 9(1) in the territory to which the alien would be returned.

Since then, the issue (again an Article 9 matter) has been given even more extensive consideration by the Court of Appeal in Ahsan Ullah v Special Adjudicator and Thi Lien Do $v$ Secretary of State for the Home Department. ${ }^{101}$ The judgment was delivered by Lord Phillips, MR, who reviewed the precedents both at the ECtHR and in the UK. The judgment is both a reasoned and robust appraisal of States' obligations towards aliens under the ECHR. Thus:

The Convention was not designed to impact on the rights of states to refuse entry to aliens or to remove them. The Convention was designed to govern the treatment of those living within the territorial jurisdiction of the contracting states. ${ }^{102}$

The court described the Soering decision as 'a significant extension of the ambit of the Convention', ${ }^{103}$ though clearly one that was now widely accepted. The rationale for using the Convention to prevent expulsion was that it would be 'an affront to fundamental humanitarian principles to remove an individual to a country where there is a real risk of serious ill-treatment ... ${ }^{104}$ The court concluded that the extension of the ECHR to prevent expulsions had with one possible exception been limited to Article 3 cases. ${ }^{105}$ Against this it has to be stressed that the possibility has been acknowledged, in principle, that it could be applied to other provisions. Indeed, the court itself said that it might have been acknowledged in Bensaid as being capable of application with regard to Article $8 .^{106}$ The court's final word was to focus on

\footnotetext{
99 [2002] Immigration Appeals Reports 601.

104 [2002] EWCA Civ $1856 . \quad 102$ Ibid, para 23. 103 Ibid, para 30.

104 Ibid, para $40 . \quad 105$ Ibid, para 48.

106 Ibid. This is presumably a reference to para 46 of that case, at which the ECtHR said that 'treatment which does not reach the severity of Art 3 treatment may nonetheless breach Art 8 in its private life aspect where there are sufficiently adverse effects on physical and moral integrity', n 89 , above.
} 
Article 3 ECHR rather than the other rights. It held that a removal decision to a country that would not respect Article 9 rights would not breach the State's human rights obligations where the nature of the interference with the right to practice religion that is anticipated in the receiving State falls short of Article 3 ill-treatment. The court then finished:

It may be that this does not differ greatly, in effect, from holding that interference with the right to practice religion in such circumstances will not result in the engagement of the Convention unless the interference is 'flagrant' ${ }^{107}$

This appears to retreat a bit from the even theoretical acceptance that ECHR rights other than Article 3 could be relevant to expulsion cases by stressing the primacy of that provision. It then acknowledges that flagrant interference with or violation of a right may engage the Convention, but seems to suggest that such flagrant violation would in any case breach Article 3.

The courts are clearly well aware of the risks of extending, or being seen to extend, the scope of the ECHR. They have acted cautiously by stating that it may be possible for rights other than those based on Article 3 to affect a State's right to remove aliens, but only in the most limited cases, and have not in fact yet done so on the facts of any case. Nevertheless, it appears that indeed there is a necessity to create a second provision in any subsidiary protection instrument allowing for protection against expulsion because of at least some other human rights violations, in addition to the protection against torture or inhuman or degrading treatment. This is the more applicable as future developments in the jurisprudence of the ECtHR and the CAT Committee should be taken into consideration. The scope of the proposal should therefore be flexible enough to include these future developments, taking account of the fact that the ECHR is a living instrument.

That flexibility is accommodated in the Proposal. Under Article 35 the Commission may propose amendments for up to 18 months after the Directive has been given effect in Member States. Priority is to be given to amendments under Article 15, clearly demonstrating the significance attached to the types of harm relevant to subsidiary protection. Further changes are not ruled out, and the Commission will evaluate the implementation of the Directive at least every five years.

\section{E. Risks for life, safety or freedom arising from situations of indiscriminate violence in situations of international or internal armed conflict}

In distinction to the protection arising, concerning individual risks of human

107 Ibid, para 64. 
rights violations upon return, State practice shows also that persons are admitted, or at least protected against refoulement, if facing a threat to their life, safety or freedom as a result of indiscriminate violence arising in situations of armed conflict, or as a result of systematic or generalized violations of their human rights. In these situations it is not always possible to establish a clear individual risk. Although there seems to be, generally speaking, consensus over the need for protection in such cases, the policies in EU Member States, as to the groups or persons protected, as well as the instruments underpinning it, vary considerably. In some Member States this protection is provided for on the basis of mere political discretion or ad hoc measures. ${ }^{108}$

The extension of subsidiary protection to include victims of armed conflicts and/or situations of generalised or systematic human rights violations is perhaps the most contentious issue. State practice does not on the whole appear to suggest that States have acted on the basis of any legal obligation in according international protection to those who would fall within this provision. Thus for instance many countries have been quite adamant in insisting that refugees from the conflicts of the 1990s in the former Yugoslavia should return there. Indeed the concept of temporary protection, designed to give assistance to those in immediate need after a mass influx, indicates that States are generally not sympathetic to treating those who have fled such situations as possible beneficiaries of refugee status or subsidiary protection. But the logic of the Proposal, and the amended version, suggested that there must be some people who would have a need, perhaps an entitlement, to international protection, the foundation for which lies not in that they are covered by one of the other provisions on entitlement to protection (in which case there would be no issue as there would be no need to fit them into this third category); nor would the justification be found simply in the existence of a need for temporary protection (in which case it would be sufficient to address their needs under the temporary protection regime, which has been laid down in a separate Council Directive). ${ }^{109}$ Rather, it must be read as recognition that there is something specific, or peculiar, to situations of armed conflict, perhaps also situations of systematic or generalized violations of human rights, that should entitle those affected to subsidiary protection.

The legal issue here is whether there is anything which would justify such an entitlement, that is on the basis of existing State practice, or is this simply a reflection of the fact that some States have been willing, as a matter of political discretion and out of a wish to behave in a humanitarian way (and without feeling in any way obliged), to offer some form of refuge and protection

108 Hailbronner argues strongly against the existence of such an obligation: 'the assumption of an international legal obligation to grant protection to victims of war, civil war and general violence must still be considered as "wishful legal thinking" ': K Hailbronner, 'Principles of International Law Regarding the Concept of Subsidiary Protection', in Bouteillet-Paquet, n 6, above, 3 at 13 .

109 Council Directive 2001/55/EC, OJ L 212/12, adopted on 20 July 2001, n 21, above. 
to those affected? ${ }^{110}$ Is this category, in other words, some form of international legal wishful thinking?

The original Proposal from the European Commission extended subsidiary protection to those who were exposed to threats to their life, safety or freedom as a result of indiscriminate violence arising in situations of armed conflict, or owing to systematic or generalized violations of their human rights. This was scaled back in the revised draft of November 2002, the equivalent provision of which allowed subsidiary protection only in the case of 'serious and individual threat to a civilian's life or person by reason of indiscriminate violence in situations of international or internal armed conflict'. ${ }^{111}$ The difference is significant. The original formula clearly encompassed certain situations that fell short of armed conflicts ('systematic or generalised violations of their human rights'). ${ }^{112}$ Furthermore the changed wording in Article $15(\mathrm{c})$ is to be understood to limit further the scope of protection: provided only to persons who face an individual risk amidst indiscriminate violence. In such cases, which by their nature usually affect groups of people indiscriminately, an individual risk is often difficult to establish. Nevertheless the Proposal seems to require that the applicant can establish that, amidst generalized violence, he is singled out.

There is scope for some overlap here with the EU's Directive on temporary protection. ${ }^{113}$ This was designed to address in a pragmatic way urgent protection needs that had arisen on a mass scale, but it is not supposed to be a substitute for refugee status or subsidiary protection for those who can demonstrate that they qualify because of the individual risk to which they are exposed. ${ }^{114}$ Therefore, even if an individual has been given temporary protection, that person will still be entitled to consideration of their claims for refugee status or subsidiary protection, at the latest when the temporary protection scheme will be lifted. However, to obtain subsidiary protection on this ground the applicant would have to demonstrate that they run a real risk of serious harm on an individual basis.

In international law there does not seem to be clear guidance for non-individual risks in these situations, except for the extended definition of refugee laid down in the 1969 OAU Convention ${ }^{115}$ and the 1984 Cartagena Declaration. ${ }^{116}$

\footnotetext{
110 This does appear to be the view of Hailbronner, who nevertheless acknowledges that there may be circumstances under which 'a person may be entitled to international protection either under an extended concept of inhuman or degrading treatment or under a customary obligation to grant humanitarian assistance against an imminent and concrete danger of gross violations of human rights', Bouteillet-Paquet, n 6, above, 3 at 14.

111 Art $15(\mathrm{c})$

112 This matter is discussed above in the text subsequent to $\mathrm{n} 23$.

113 See n 21, above.

114 Ibid, Art 3(1): 'Temporary protection shall not prejudge recognition of refugee status under the Geneva Convention.'

115 Convention on the Specific Aspects of Refugee Problems in Africa 1969, 1000 UNTS 46, Art I(2).

116 OAS/Ser.L/V/II.66, doc 10, rev 1, Conclusion III(3)
} 
European States have, however, not explicitly committed themselves to such a policy. As far as armed conflicts are concerned, perhaps some guidance may be obtained from the Geneva Conventions of 12 August 1949 on the protection of victims of armed conflicts. Especially the common Article 3 of these Conventions may offer guidance for an implicit prohibition of refoulement in these cases where civilians as a group are at risk in situations of internal conflicts.

In the case of armed conflict not of an international character occurring in the territory of one of the High Contracting Parties, each Party to the conflict shall be bound to apply, as a minimum, the following provisions:

(1) Persons taking no active part in the hostilities, including members of armed forces who have laid down their arms and those placed hors de combat by sickness, wounds, detention, or any other cause, shall in all circumstances be treated humanely, without any adverse distinction founded on race, colour, religion or faith, sex, birth or wealth, or any other similar criteria.

To this end the following acts are and shall remain prohibited at any time and in any place whatsoever with respect to the above-mentioned persons:

(a) violence to life and person, in particular murder of all kinds, mutilation, cruel treatment and torture;

(b) taking of hostages;

(c) outrages upon personal dignity, in particular humiliating and degrading treatment;

(d) the passing of sentences and the carrying out of executions without previous judgment pronounced by a regularly constituted court, affording all the judicial guarantees which are recognized as indispensable by civilized people ...

In principle only parties involved in the conflict are bound by the provisions of the 1949 Geneva Convention for the protection of civilians in armed conflicts. However the ICJ has made it clear that States not directly involved in a conflict may be obliged to observe these provisions in order to protect civilians. ${ }^{117}$ Although there is little evidence to claim a principle of nonrefoulement on the basis of Article 3 for victims of civil war and other internal upheavals, it can at least be stated that an implicit principle has developed here for States. Host States need to respect Article 3 in their consideration as to whether or not to return an applicant to a country in civil war.

Apart from the possible impact of common Article 3, which was supposed to reflect the most serious threats, the grave breaches regime of the Conventions may also assist. The seriousness of the threat posed by grave breaches of the Conventions to basic human rights is widely acknowledged, even to the extent of specific inclusion in the Statute of the International

117 ICJ Reports 1986, 14 (Nicaragua v USA), para 220: 'The Court considers that there is an obligation on the United States Government ... to "respect" the Conventions and even "to ensure respect" for them "in all circumstances" ...' 
Criminal Tribunal for the Former Yugoslavia118 and the Statute of the International Criminal Court. ${ }^{119}$ The latter instrument furthermore includes a rather wide list of breaches of human rights under the headings of genocide, war crimes and crimes against humanity, all of which are designated as 'the most serious crimes of concern to the international community as a whole' ${ }^{120}$ The adoption of the Statute with the support of a very large group of States in 1998 demonstrates the widespread acceptance of the seriousness of these crimes. ${ }^{121}$ These are not parking offences.

Clearly, some of the crimes included in these instruments would, if threatened, activate the application of one or more of the other bases of subsidiary protection (even taking the EU proposals at their narrowest): death penalty or execution; torture or inhuman or degrading treatment or punishment of an applicant in his or her country of origin. But in the case of armed conflicts, while the threat may be from within the home State (either by a foreign occupier or from the other side in a civil conflict), it could also arise in a country to which he or she has been forcibly removed. In such a case, should the individual succeed in escaping it may not be feasible to return to their home State because of the serious threats posed to their human rights there. In the absence of the application of some other provision of the subsidiary protection regime, given the seriousness of the threat that may exist, it is suggested that the notion of a 'serious and individual threat to a civilian's life or person by reason of indiscriminate violence in situations of international or internal armed conflict' needs to be interpreted more widely rather than more narrowly if States are to remain within the law.

The threat posed by general situations of violence, whether or not involving an armed conflict, may often include the types of breach that would activate one of the other grounds of subsidiary protection, such as torture or inhuman or degrading treatment. To this extent there is some overlap but clearly the scope of this protection must, to some extent, be different; otherwise, as suggested above, it would serve no useful purpose. There must be some real and serious risk that is posed to the individual, a risk which is nevertheless not addressed by the other categories of entitlement to protection. That threat may not necessarily amount to persecution in the sense that refugee law understands that term. The UNHCR, in its observations on the original Proposal, acknowledged that there were 'refugees of concern' to it who did not fall under the strict scope of the Geneva Convention and Protocol. ${ }^{122}$ It specifically included within this group those fleeing the indiscriminate effects of

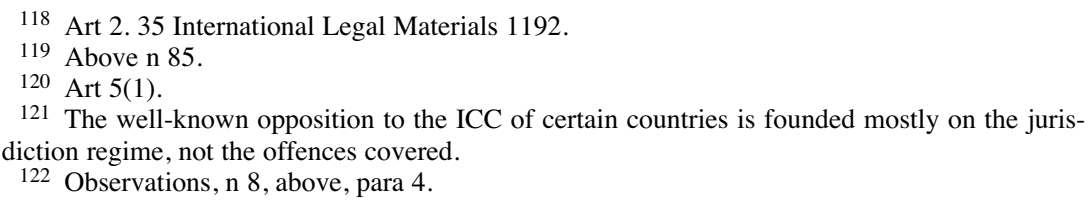


violence arising in situations of armed conflict. ${ }^{123}$ It asserted that subsidiary protection could be particularly important for such persons. ${ }^{124}$

This third category of persons - those who are the object of serious threats, whether as a result of indiscriminate violence in armed conflicts or systematic or generalised violations of human rights - is the most problematic in terms of identifying State practice that would confirm the existence of a right to subsidiary protection. However, even in the absence of clear State practice, there is certainly a legal context, outlined above, of which States must be aware when deciding on entitlement to subsidiary protection. To the extent that other human rights threats are accepted as giving rise to a right to subsidiary protection (because they are non-derogable or because they might amount to a flagrant breach or violation of a derogable right), that context suggests that mere adherence to the EU Proposal, as set out in November 2002, will not be enough to meet existing international obligations.

\section{CONCLUSION}

In our view the obligation to grant subsidiary protection exists with regard to the following (assuming that they do not qualify for refugee status), if there is a serious risk of the listed danger or threat transpiring:

- those who would be subject to the death penalty or execution;

- those who would be subject to torture or inhuman or degrading treatment or punishment;

- those who would be subject to a breach of one of the other non-derogable rights typical of general multilateral human rights instruments;

- (probably) those who would be subject to a breach of a derogable right, where such a breach would constitute a flagrant denial or violation of the individual's rights in the country to which they are to be returned (ie, not every potential breach of a derogable right would give rise to a possible duty to provide subsidiary protection);

- those who are subject to a serious and individual threat to their life or person as a consequence of indiscriminate violence during situations of armed conflict.

Evidence can be found in international law and State practice for the assertion that persons who face threats of indiscriminate violence without a clearly established individual risk are eligible for subsidiary protection. It is apparent, though (not in the least because of the changes made in Article 15(c) as described above) that States are of the opinion that whenever protection is

$$
123 \text { Ibid. } \quad{ }^{124} \text { Ibid, para } 42 .
$$


granted in these cases it is not based upon legal obligation, but die to compassionate or humanitarian reasons. In our view the notion 'individual risk' should not be interpreted narrowly as to do so would remove the need to provide a separate paragraph 15(c) in addition to paragraph 15(b).

Based upon the distinction between derogable and non-derogable human rights, evidence can also be found to include those who are subject to a serious and individual threat to their life or person as a consequence of systematic or generalised violations of their human rights within the scope of subsidiary protection. Whether this interpretation will be accepted remains to be seen, especially because these cases have been removed from the Proposal on purpose. This will give the European Court of Justice less room for an extensive interpretation. At the same time, State practice shows that persons in such cases are not actively returned to their countries of origin. This attitude of States is at least an indication that they feel constrained in their exercise of this competence.

To the extent that EU law fails to meet these requirements in the Directive on qualification for refugee status and subsidiary protection, Member States which adhere only to its minimum standards will be in breach of their international obligations. Given that the Directive is supposed to be at the core of the common European asylum policy, it raises the spectre of that policy being based on false standards.

Furthermore, as the Directive focuses mainly on Article 3 ECHR cases, there may be a lack of flexibility in the Directive to cover future developments in the jurisprudence of the ECtHR. It can not be excluded that in other cases the ECtHR may explicitly derive State obligations not to extradite an alien from one of the other non-derogable human rights laid down in the ECHR. In such cases, the Directive most likely will not cover all persons entitled to subsidiary protection. The consequence will then be a gap in terms of EUharmonisation on this topic.

On the other hand, it can be stated that the Directive, already in the present wording, does not entirely codify State practice of granting some form of temporary status based on humanitarian or compassionate reasons which are not clearly based on international protection. ${ }^{125}$ These aspects will be left to the discretion of Member States. As a consequence, the Directive will only partially harmonise the current State practice to provide for other forms of protection besides the 1951 Geneva Convention.

\footnotetext{
125 This is clearly stated in the following recital in the Preamble: 'Whereas those third country nationals or stateless persons, who are allowed to remain in the territories of the Member States for reasons not due to a need for international protection but on a discretionary basis on compassionate or humanitarian grounds, fall outside the scope of this Directive', Asile 77, 15068 of 13 Dec 2002.
} 
Therefore there will be three groups in need of protection: Convention refugees, persons entitled to subsidiary forms of protection based upon the Directive and other persons in need of protection regulated under varying national law or policy in the Member States. As a first step towards harmonisation, the Directive can be seen as an important step forward, but should not be the final objective. In terms of harmonization, it would be desirable to initiate further discussion on a further EU-instrument which covers all persons in need of international protection. 